\title{
Mitral valve surgery using right anterolateral thoracotomy: is the aortic cannulation a safety procedure?
}

\author{
Cirurgia valvar mitral via toracotomia ântero-lateral direita: a canulação aórtica é segura?
}

Marco Antonio Vieira GUEDES ${ }^{1}$, Pablo Maria Alberto POMERANTZEFF², Carlos Manuel de Almeida BRANDÃO², Marcelo Luiz Campos VIEIRA ${ }^{4}$, Max GRINBERG ${ }^{5}$, Noedir Antonio Groppo STOLF ${ }^{6}$

RBCCV 44205-1193

\section{Resumo}

Introdução: A toracotomia ântero-lateral direita tem sido utilizada como uma alternativa para a abordagem cirúrgica da valva mitral. Nestes casos, a canulação femoral continua sendo utilizada, possibilitando a ocorrência de complicações.

Objetivo: Descrever a técnica e os resultados do tratamento da valva mitral via toracotomia ântero-lateral direita, utilizando a canulação aórtica para instalação da circulação extracorpórea.

Métodos: Entre 1983 e 2008, 100 pacientes consecutivos, com média de idade $35 \pm 13$ anos, 96 (96\%) do sexo feminino, foram submetidos ao tratamento cirúrgico da valva mitral no InCor-HC-FMUSP, através da toracotomia ântero-lateral direita associada à canulação aórtica. Destes, 80 (80\%) pacientes apresentavam etiologia reumática e $84(84 \%)$ classe funcional III ou IV.

Resultados: Foram realizadas 45 (45\%) comissurotomias, 38 (38\%) plásticas, sete $\mathbf{( 7 \% )}$ substituições da valva mitral, sete $(7 \%)$ re-comissurotomias e três $(3 \%)$ substituição de prótese mitral. Cirurgia conservadora foi realizada em 90

1. Doutor em Ciências FMUSP; Professor Substituto da Faculdade de Medicina da Universidade Federal da Bahia.

2. Professor Associado do Departamento de Cardiopneumologia da FMUSP; Diretor da Unidade Cirúrgica de Cardiopatias Valvares do InCor - HC - FMUSP.

3. Doutor em Medicina FMUSP, Médico Assistente - Divisão Cirúrgica - Incor - HC - FMUSP Professor Colaborador - FMUSP.

4. Doutor em Medicina FMUSP; Médico Assistente - Divisão de Ecocardiografia - InCor - HC - FMUSP.

5. Professor Livre-Docente da FMUSP, Diretor da Unidade Clínica de Cardiopatias Valvares InCor - HC - FMUSP.

6. Professor Titular da Disciplina de Cirurgia Cardiovascular da FMUSP, Diretor da Divisão de Cirurgia do InCor - HC - FMUSP.
(90\%) dos pacientes. O tempo médio de CEC e pinçamento foi $57 \pm 27 \mathrm{~min}$ e $39 \pm 19 \mathrm{~min}$, respectivamente. Não ocorreram óbitos hospitalares, reoperações por sangramento ou conversão para esternotomia. Complicações intraoperatórias foram relacionadas à dissecção cardíaca (5\%), principalmente nas reoperações (3\%). As principais complicações pós-operatórias foram relacionadas ao sistema pulmonar (11\%), seguidas de fibrilação atrial $(10 \%)$, porém sem repercussões sistêmicas graves. A média de internação hospitalar foi de $8 \pm 3$ dias. O seguimento foi 6.038 pacientes/ mês. A sobrevida atuarial e livre de reoperação foi de $\mathbf{9 8 , 0} \pm$ $1,9 \%$ e 81,4 $\pm 7,8 \%$ em 180 meses, respectivamente.

Conclusão: A utilização da toracotomia ântero-lateral direita associada a canulação aórtica na abordagem cirúrgica da valva mitral é uma técnica simples, reprodutível e segura.

Descritores: Valva mitral. Circulação extracorpórea. Cirurgia torácica. Valvas cardíacas. Procedimentos cirúrgicos minimamente invasivos.

Trabalho realizado no INCOR - Instituto do Coração da Faculdade de Medicina da Universidade de São Paulo, São Paulo, SP, Brasil

Endereço para correspondência:

Marco Antonio Vieira Guedes

Av. Dr. Enéas de Carvalho Aguiar, 44 - São Paulo, SP, Brasil. CEP: 05403-000.

E-mail: guedesmarco@gmail.com 
patients. The average $\mathrm{CPB}$ and clamp time were $57 \pm 27 \mathrm{~min}$ e $39 \pm 19$ min, respectively. There were no in-hospital death, reoperation due to bleeding and convertion to sternotomy. Introperative complications were related to heart harvest (5\%), especially in reoperations (3\%). The most important complications in postoperative period were related to pulmonary system (11\%), followed by atrial fibrilation (10\%) but without major systemic repercussions. The mean inhospital length of stay was $8 \pm 3$ days. Follow-up was 6.038 patients/month. Actuarial survival was $98.0 \pm 1.9 \%$ and freedom from reoperation was $81.4 \pm 7.8 \%$ in 180 months.

Conclusion: The right anterolateral thoracotomy associated with aortic cannulation in mitral valve surgery is a simple technique, reproducible and safety.

\section{presented functional class III or IV.} patients had rheumatic disease and $84(84 \%)$ patients

Results: Were performed 45 (45\%) comissurotomies, 38 (38\%) valve repairs, $7(7 \%)$ mitral valve replacements, seven (7\%) recomissurotomies and three $(3 \%)$ prosthesis replacement. Sparing surgery was performed in 90 (90\%)

\section{INTRODUCTION}

Right thoracotomy approach to perform mitral valve surgery was described, in 1954, by Neptune \& Bailey [1] and has been widely used until nowadays, with excellent exposure of mitral valve, even in small left atrium. This incision presents favorable cosmetic results, representing a good alternative in young female patients [2].

Despite of it, the midline sternotomy is by far the most common incision for open heart operations, including mitral valve surgery, due to easy access to all cardiac chambers and great vessels [3].

In the 1980's, some authors revisited the mitral valve approach through right thoracotomy in redo cases to avoid sternotomy, minimizing the risk of cardiac damage [4]. Furthermore, was suggested that a limited anterolateral thoracotomy should be preferred to an extended lateral thoracotomy, in order to minimize postoperative pulmonary complications, because it provides a good operative exposure and preserves the integrity of thoracic cage [3-5]. Besides, limited thoracotomy is associated to less infection occurrence, less bleeding and earlier postoperative recovery [5].

Femoral cannulation is associated to many complications, such as infection, bleeding, thrombosis and late stenosis, cerebral and coronary embolism [6]. Despite, femoral cannulation is the most common approach to cardiopulmonary bypass in mitral valve surgery through a limited anterolateral thoracotomy [3-5]. This approach allows complications occurrence related with femoral cannulation [6].

The aim of this study was to describe the technique and results of mitral valve surgery through a limited right thoracotomy using aortic cannulation for cardiopulmonary bypass.

\section{METHODS}

From 1983 through 2008, 100 consecutive patients underwent mitral valve surgery at Heart Institute of University of São Paulo Medical School through a right anterolateral thoracotomy associated with aortic cannulation for cardiopulmonary bypass. This approach to mitral valve was performed in female patients with low risk profile, in order to achieve a better cosmetic result, and in redo cases, to avoid sternotomy and minimize surgical bleeding. Ninety six (96\%) of patients were female. The mean of age was $35 \pm 13$ years (range 13 to 68 years). According to etiology, 80 (80\%) were rheumatic, four (4\%) congenital, six (6\%) degenerative, fi (5\%) endocardites and five (5\%) miscellaneous. According to NYHA, in the preoperative period, two (2) were in functional class I, 14 (14\%) in II, 69 (69\%) in III and $15(15 \%)$ were in functional class IV. Associated procedures were performed in $12(12 \%)$ patients. Ten $(10 \%)$ cases were reoperation procedures. Operative and associated procedures performed are shown in Table 1.

Table 1. Surgical data.

\begin{tabular}{lcc}
\hline Operative procedures & $\mathrm{n}$ & $\%$ \\
\hline Mitral valve comissurotomy & 45 & 45 \\
Mitral valve repair & 38 & 38 \\
Mitral valve replacement & 7 & 7 \\
Recomissurotomy & 7 & 7 \\
Prosthesis replacement & 3 & 3 \\
Associated procedures & & \\
Atriosseptoplasty & 6 & 6 \\
Tricuspid valve repair & 6 & 6 \\
\hline
\end{tabular}


Data was abstracted from hospital and clinic charts using a special protocol form and were retrospectively analyzed. Follow-up of these patients was obtained by postoperative clinical and echocardiographic evaluations in the outpatients clinic or telephone interview using a structured questionnaire. The Kaplan-Meier method was used to evaluate actuarial survival.

\section{Operative technique}

After monitorization and endotracheal anesthesia, the patient was moved to a left semi-lateral position and maintained at an angle of $45^{\circ}$ of operating table to expose the right hemithorax. The patient was draped in usual manner. A 10-12 cm incision was made in the right submammary fold, starting 3-5 cm from the lateral border of the sternum. Breast tissue was mobilized and pleural cavity was entered through $4^{\text {th }}$ intercostal space. Chest retractor was progressively opened to avoid ribs fracture. Pericardial sac was opened through a horizontal incision as anterior as possible, avoiding phrenic nerve and providing exposure of the ascending aorta.The pericardium was fixed to the wound edge with heavy silk sutures starting near the diaphragm, finishing at aorta reflection. This maneuver is very important to pull down the ascending aorta, achieving a clear exposure of aorta and lateral wall of heart. A moynihan clamp was placed in anterior surface of ascending aorta and a gently traction was made to exposure the site for aortic cannulation.

After a temporary induced hypotension, ascending aorta was cannulated in usual manner and secured by a Rommel tourniquette. Aortic cannula was fixed in a column of towels to avoid kinking position, as shown in Figure 1. After that, bicaval cannulation was performed. As shown in Figure 2, aortic cross clamping was performed using a long curved clamp. Cardioplegia was delivered at aortic root. Mitral valve surgery was performed and decannulation was done

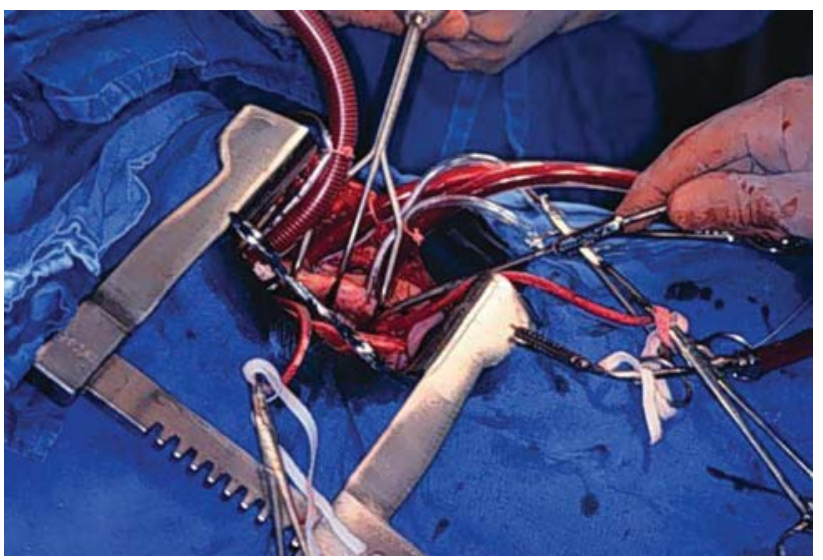

Fig. 1 - Aortic cannula position. The cannula was fixed in a column of towels to avoid kinking position

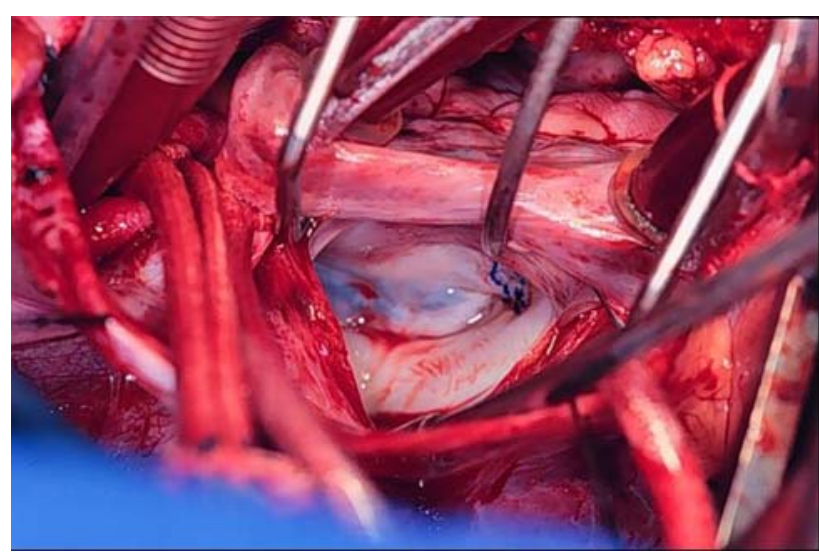

Fig. 2 - Aortic cross clamp using a long curved aortic clamp

in usual manner. Pleural cavity was drainage by one chest tube and chest closed in layers.

\section{RESULTS}

Aortic cannulation was performed in all cases and there were no technical difficulties or complications related to the cannulation. There were intraoperative complications in five (5\%) cases: right ventricle perforation in one, inominnate vein rupture in one, pulmonary artery lesion in one, ribs fracture in one and pulmonary contusion in one patient. From these complications, three (3\%) of them were in reoperation procedures, occurring during heart harvesting. There was no conversion to median sternotomy.

The most important complication in postoperative period was related to pulmonary system, occurring in 11 (11\%) patients, but without seriously systemic disorders. Of them, atelectasis occurred in seven (7\%) patients, pleural effusion, pneumothorax, pleural fistula, pulmonary thromboembolism, transitory encefalophathy and wound dehiscence occurred in one patient each postoperative complication. Atrial arrythmia occurred in 10 (10\%) patients. There was no reoperation due to postoperative bleeding.

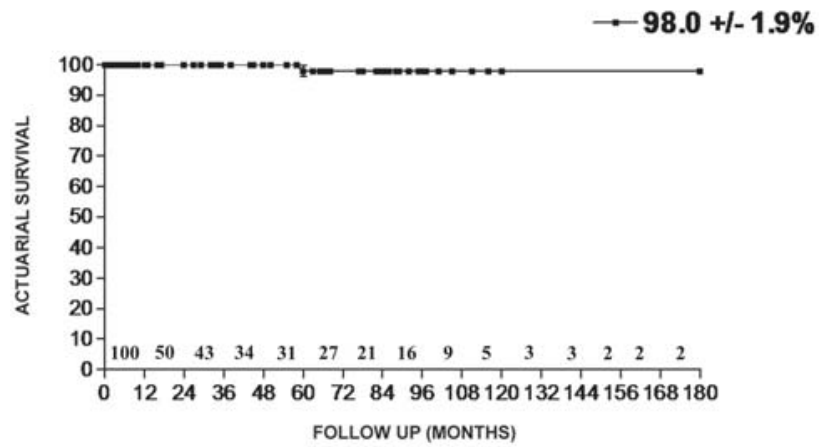

Fig. 3 - Actuarial survival 
There was no in-hospital death. The mean in-hospital length of stay was $8 \pm 3$ days. Follow-up was 503 patients/ year. In late postoperative period, according to NYHA, 80 $(80 \%)$ of patients were in functional class I, nine (9\%) in II and two (2\%) in functional class III. Actuarial survival was $98.0 \pm 1.9 \%$ (Figure 3 ) and freedom from reoperation was $81.4 \pm 7.8 \%$ in 180 months (Figure 4 ).

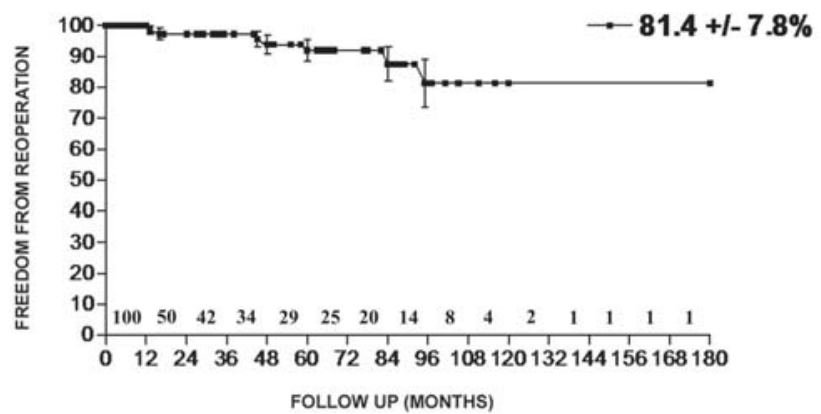

Fig. 4 - Freedom from reoperation

\section{DISCUSSION}

The surgical approach to mitral valve through right thoracotomy offers an excellent exposure of the mitral valve, even in patients with small left atrium [2]. Furthermore, associated procedure as closure of atrial septal defect or tricuspid valve surgery can be executed by this approach safely [3].

One of the most important aspects of this technique is the excellent cosmetic result obtained. The scar usually is covered by breast tissue in female patients. Moreover, complications related to sternotomy, as sternal infection or bleeding, is avoided with this technique $[3,5]$. One of the principal concern about less invasive surgery is the balance between limited exposure and safety of the procedure. In this study, there was no reoperation due to bleeding or inhospital death, what demonstrates the safety of the limited right thoracotomy. This fact probably could be related to the team experience, and also to the low risk profile of the patients included in this study.

Femoral cannulation for bypass was usually performed in mitral valve operations using right thoracotomy. The use of femoral vessels can predispose to complications such as bleeding, dissection, thrombosis, stenosis, lower limb ischemia, lymphatic leakage, local infection and embolic events [6]. The most hazardous complication related to femoral cannulation is retrograde aorta dissection, that can be progressive, with extension to aortic arch or to retroperitonial space. The mortality of this event is high, and its incidence in femoral cannulation ranges between 0.2 and $1.3 \%$ [7].

Kirklin and Barratt-Boyes [8] related that one of the disadvantages of this technique is the relative inaccessibility to thoracic aorta. In this report, ascending aorta was cannulated and clamped with safety and without complications in all cases, demonstrating the feasibility of this technique. Less invasive methods have been successfully developed and represent valuable alternatives for mitral valve surgery. Reduction in surgical trauma is the angle key to improve patient comfort and reduce hospital stay. Furthermore, development of novel technologies as robotics and video-assisted thoracoscopy surgery enables implementation of this approach on clinical practice [9].

Limited right anterior thoracotomy associated with aortic cannulation in mitral valve surgery is a simple technique, reproducible and safe. Furthermore, complications related to femoral cannulation were avoided with this technique.

\section{REFERENCES}

1. Neptune WB, Bailey CP. Mitral commissurotomy through the right thoracic approach: technique and indications. J Thorac Surg. 1954;28(1):15-22.

2. Kumar AS, Prasad S, Rai S, Saxena DK. Right thoracotomy revisited. Tex Heart Inst J. 1993;20(1):40-2.

3. Wang YQ, Chen RK, Ye WW, Zhong BT, He QC, Chen ZL et al. Open-heart surgery in 48 patients via a small right anterolateral thoracotomy. Tex Heart Inst J. 1999;26(2):124-8.

4. Berreklouw E, Alfieri O. Revival of right thoracotomy to approach atrio-ventricular valves in reoperations. Thorac Cardiovasc Surgeon. 1984;32(5):331-3.

5. El-Fiky MM, El-Sayegh T, El-Beishry AS, Aziz MA, Enein HA, Waheid S, et al. Limited right anterolateral thoracotomy for mitral valve surgery. Eur J Cardiothorac Surg. 2000;17(6):710-3.

6. Salerno TA, Lince DP, White DN, Lynn RB, Charrette EJ. Arch versus femoral artery perfusion during cardiopulmonary bypass. J Thorac Cardiovasc Surg. 1978;76(5):681-4.

7. Bilgutay AM, Garamella JJ, Danyluk M, Remucal HC. Retrograde aortic dissection occurring during cardiopulmonary bypass. Successful repair and concominant subclavian-tocoronary artery vein bypass. JAMA. 1976;236(5):465-8.

8. Kirklin JW, Barratt-Boyes BG. Mitral valve disease with or without tricuspid valve disease. In: Kirklin JW, Barratt-Boyes BG, eds. Cardiac surgery. New York:Wiley;1986. p.364.

9. Grossi EA, Galloway AC, LaPietra A, Ribakove GH, Ursomanno P, Delianides J, et al. Minimally invasive mitral valve surgery: a 6-year experience with 714 patients. Ann Thorac Surg. 2002;74(3):660-4. 